\title{
Awareness and Perception of Farmers towards Soil Health Card Scheme in Rayalaseema Region of Andhra Pradesh, India
}

\author{
S. Lokesh Babu*, T. Lakshmi and S.V. Prasad \\ Department of Agricultural Extension, S.V. Agricultural College, Tirupati, India \\ *Corresponding author
}

\begin{tabular}{l} 
Key w o r d s \\
Perception, \\
Farmers, Soil \\
Health, Card \\
Scheme \\
\hline Article Info \\
Accepted: \\
17 May 2019 \\
Available Online: \\
10 June 2019
\end{tabular}

\section{Keywords}

Perception, Farmers, Soil Health, Card Scheme

Article Info

17 May 2019

10 June 2019

\section{A B S T R A C T}

The basic objective of soil testing programme is to give farmers a service leading to better and more economic use of fertilizers and soil management practices for increasing agricultural production. Now a day's consumption of fertilizer by farmer is higher than actual requirement. The farmers do not follow the soil testing technique. Soil test based nutrient management has emerged as a key issue in efforts to increase agricultural productivity and production since optimal use of nutrients, based on soil analysis can improve crop productivity and minimize wastage of these nutrients, thus minimizing impact on environmental leading to bias through optimal production. Governments do efforts towards these through Soil Health Cards. The above study was conducted in Anantapuramu district of Andhra Pradesh. Six mandals were selected for the study. From each mandal two villages were selected and from each village 20 SHC beneficiaries were selected thus comprising 240 respondents for the study. The data were collected with help of well-structured interview schedule following personal interview methods. The data revealed that major constraints faced by SHC beneficiaries in utilizing the soil health card were, Difficulty in calculating fertilizer dose on the basis of nutrient status of soil (85.84\%), receiving soil health cards after crop harvest (82.51\%), time gap between soil samples taken and issuing cards is too high (79.17\%), and collection of soil sample was not done in presence of farmers $(72.92 \%)$.

\section{Introduction}

Agriculture is the backbone of Indian economy. Progress of India is very much dependent on the development of agriculture. The increased agricultural production depends upon number of factors of which soil fertility plays an important role. Soil fertility is identified by the nutrient status of the soil. Soil fertility is identified by the nutrient status of the soil. Soil testing has been used by soil scientist as an aid in determining soil fertility level. Yadav et al., (2006) stated that soil testing has exposed some information about the accurate amount of nutrients of special kinds of plants and also other information such as acid and saline-alkali soil.

The basic objective of soil testing programme is to give farmers a service leading to better and more economic use of fertilizers and soil management practices for increasing 
agricultural production. Now a day consumption of fertilizer by farmer is higher than actual requirement. The farmers do not follow the soil testing technique. Hence to reduce the over consumption of fertilizers and follow the soil test based recommendation for applying fertilizers government has launched soil health card scheme in February 2015. Soil Health Card is one of the important approaches in agriculture because it is key elements for the sustainable production is soil which serves as a natural nutrient source for growth of plants.

A SHC is meant to give each farmer soil nutrient status of his holding and advise him on the dosage of fertilizers and micronutrient and also the needed soil amendments that he should apply to maintain soil health in the long run. The scheme is considered as a holistic measure for soil health and farm economy. A SHC carries crop wise recommendation of nutrients and fertilizer required for the individual farms to help farmers to improve productivity through judicious use of inputs. In this programme, technical guidelines are given on how to collect the soil samples and where to test it. The job of soil testing is done in soil testing labs \& mini kit at KVKs across the country. The experts in this line will analyze the strength and weakness (micro-nutrient deficiency) of the soil and suggest measure to deal with and the concerned department will distribute the cards among farmers of each state. In the guidelines, there is also an instruction to devise a mechanism to issue SHC every 3 years in respect of all holdings in order to capture the soil fertility changes occurring due to plant uptake or other natural causes. Awareness on SHC by conducting meetings, trainings, group discussions, exhibition and demonstrations at village level based on the importance of SHC. The present study throws a light on awareness, perception and constraints faced by the farmers in adoption of soil test techniques and its recommendations.

\section{Materials and Methods}

The present study was conducted in Rayalaseema region of Andhra Pradesh state. Anantapuramu district was selected for the study because there exists diversified crops which require different types of soils. Six mandals from Anantapuramu district were selected randomly by following lottery method of simple random sampling. Ten mandals with highest number of soil health card holders were selected and from ten mandals six mandals namely Raptadu, Kanekal, Tadipatri, Gudibanda, Dharmavaram, Gorantla were selected randomly by following lottery method of sampling. Two villages were selected from each of the 6 mandals by following simple random sampling thus making a total of 12 villages. From each village, 20 farmers were selected by following simple random sampling procedure, thus making a total of 240 respondents who were having soil health cards had been selected for the study.

The data were collected through personal interview method with the help of prestructured scheduled designed with the objective finding out awareness level \& perception regarding utility of SHC and to analyze the constraints and suggestions expressed by farmers in utilization of SHC. The data collected was subjected to suitable technique of analysis by regression.

\section{Results and Discussion}

The data related to constraints faced by the respondents are presented in table 1 and ranked as I) Difficult to calculate fertilizer dose on the basis of nutrient status of soil (85.84\%). II) Received soil health cards after crop harvest (82.51\%). III) Time gap between 
soil samples taken and issuing cards is too high (79.17\%). IV) Collection of soil sample was not done in presence of farmers $(72.92 \%)$. V) Lack of technical advice on method and time of fertilizer application (69.59\%). VI) Recommended fertilizers not available in adequate quantity in local market (63.34\%). VII) Soil testing labs are located far away (54.59\%). VIII) High price of fertilizers $(52.92 \%)$. IX) Doubt on the quality and reliability of the information provided in the SHC (46.67\%). X) Lack of training (37.50\%).
XI) Unable to operate internet (access to soil health card portal) (34.59\%). XII) Irregularity of extension services $(30.84 \%)$. Thus, it can be concluded that major constraints faced by the SHC holders about Soil Health Card were Difficult to calculate fertilizer dose on the basis of nutrient status of soil followed by Received soil health cards after crop harvest followed by Time gap between soil samples taken and issuing cards is too high and Collection of soil sample was not done in presence of farmers.

\begin{tabular}{|c|c|c|c|c|}
\hline State & District & Mandals & Villages & Respondents \\
\hline \multirow{12}{*}{ Andhra Pradesh } & \multirow{12}{*}{ Anantapuramu } & \multirow[t]{2}{*}{ Raptadu } & Bommaparthy & 20 \\
\hline & & & Hampapuram & 20 \\
\hline & & \multirow[t]{2}{*}{ Kanekal } & Kanekal & 20 \\
\hline & & & Ganigera & 20 \\
\hline & & \multirow[t]{2}{*}{ Tadipatri } & Peddapolamada & 20 \\
\hline & & & Alur & 20 \\
\hline & & \multirow[t]{2}{*}{ Gudibanda } & Muthukuru & 20 \\
\hline & & & Morubagal & 20 \\
\hline & & \multirow[t]{2}{*}{ Dharmavaram } & Kunuthuru & 20 \\
\hline & & & Chigicherla & 20 \\
\hline & & \multirow[t]{2}{*}{ Gorantla } & Gowrivaripalle & 20 \\
\hline & & & Vanavolu & 20 \\
\hline Total & 1 & 6 & 12 & 240 \\
\hline
\end{tabular}

Table.1 Distribution of the SHC holders according to the constraints faced by them in using Soil health card

\begin{tabular}{|c|l|c|c|c|}
\hline S. No & \multicolumn{1}{|c|}{ Constraints } & Frequency & Percentage & Rank \\
\hline $\mathbf{1}$ & $\begin{array}{l}\text { Recommended fertilizers not available in adequate quantity in local } \\
\text { market }\end{array}$ & 152 & 63.34 & VI \\
\hline $\mathbf{2}$ & High price of fertilizers & 127 & 52.92 & VIII \\
\hline $\mathbf{3}$ & Lack of technical advice on method and time of fertilizer application & 167 & 69.59 & V \\
\hline $\mathbf{4}$ & Difficult to calculate fertilizer dose on the basis of nutrient status of soil & 206 & 85.84 & I \\
\hline $\mathbf{5}$ & Received soil health cards after crop harvest. & 198 & 82.51 & II \\
\hline $\mathbf{6}$ & Doubt on the quality and reliability of the information provided in the & 112 & 46.67 & IX \\
\hline & SHC & & & \\
\hline $\mathbf{7}$ & Lack of training & 90 & 37.50 & X \\
\hline $\mathbf{8}$ & Unable to operate internet (access to soil health card portal) & 190 & 74.59 & XI \\
\hline $\mathbf{9}$ & Time gap between soil samples taken and issuing cards is too high & 175 & 72.17 & III \\
\hline $\mathbf{1 0}$ & Collection of soil sample was not done in presence of farmers & 74 & 30.84 & IV \\
\hline $\mathbf{1 1}$ & Irregularity of extension services & 131 & 54.59 & VII \\
\hline $\mathbf{1 2}$ & Soil testing labs are located far away & & & \\
\hline
\end{tabular}


Table.2 Distribution of the SHC holders according to the suggestions offered by them in using Soil health card

\begin{tabular}{|c|c|c|c|c|}
\hline S.No & Suggestion & Frequency & Percentage & Rank \\
\hline 1 & $\begin{array}{l}\text { Soil sampling procedure should be done } \\
\text { in presence of farmer }\end{array}$ & 205 & 85.42 & II \\
\hline 2 & $\begin{array}{l}\text { Farmer should be trained to take soil } \\
\text { sample of his own soil }\end{array}$ & 161 & 67.08 & VI \\
\hline 3 & $\begin{array}{l}\text { Soil testing laboratory should be } \\
\text { established at taluka level with highly } \\
\text { qualified staff }\end{array}$ & 150 & 62.50 & VII \\
\hline 4 & $\begin{array}{l}\text { Provide training for better understanding } \\
\text { about content of Soil Health Cards }\end{array}$ & 170 & 70.83 & $\mathrm{~V}$ \\
\hline 5 & $\begin{array}{l}\text { Crop wise recommended dose of fertilizer } \\
\text { should be given in SHC }\end{array}$ & 220 & 91.67 & I \\
\hline 6 & $\begin{array}{l}\text { Government should provide SHC every } \\
\text { year to each farmer. }\end{array}$ & 193 & 80.42 & IV \\
\hline 7 & SHC should be issued prior to crop season & 200 & 83.34 & III \\
\hline 8 & $\begin{array}{l}\text { Government should provide subsidy on } \\
\text { inputs used by farmers }\end{array}$ & 145 & 60.42 & VIII \\
\hline 9 & $\begin{array}{l}\text { Ensure availability of recommended } \\
\text { fertilizers in the market }\end{array}$ & 130 & 54.17 & IX \\
\hline 10 & $\begin{array}{l}\text { Proper and timely agriculture extension } \\
\text { services }\end{array}$ & 80 & 33.33 & $X$ \\
\hline
\end{tabular}

\section{constraints}

Soil testing labs are located far away Irregularity of extension services Collection of soil sample was not done in...

Time gap between soil samples taken and.. Unable to operate internet (access to soil... Lack of training Doubt on the quality and reliability of the... Received soil health cards after crop harvest. Difficult to calculate fertilizer dose on the... Lack of technical advice on method and... High price of fertilizers Recommended fertilizers not available in...

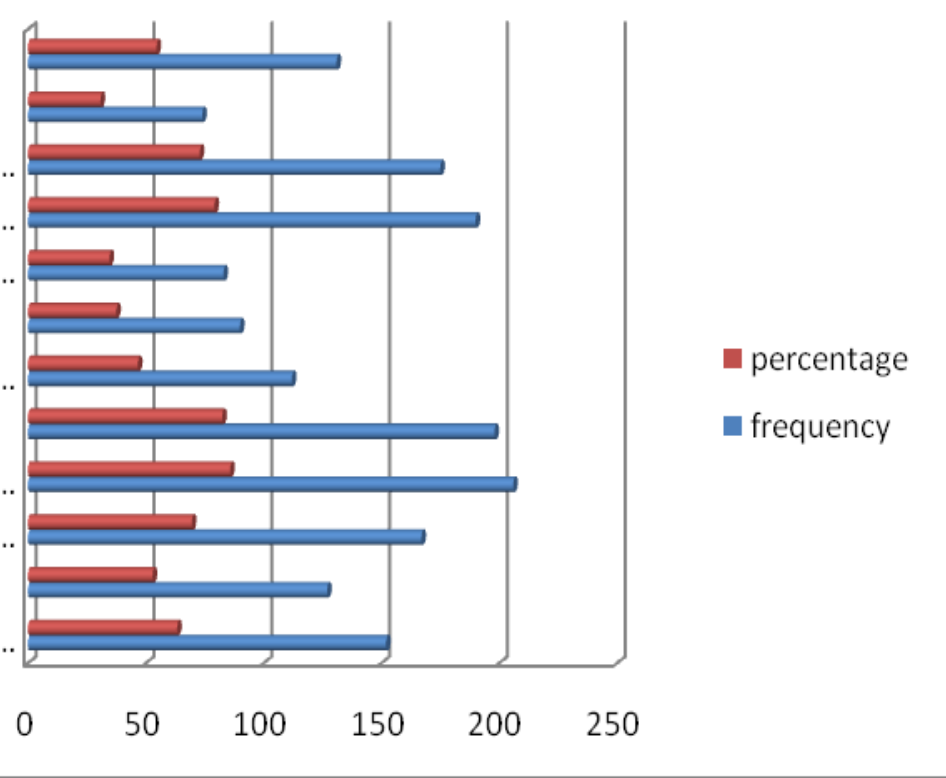




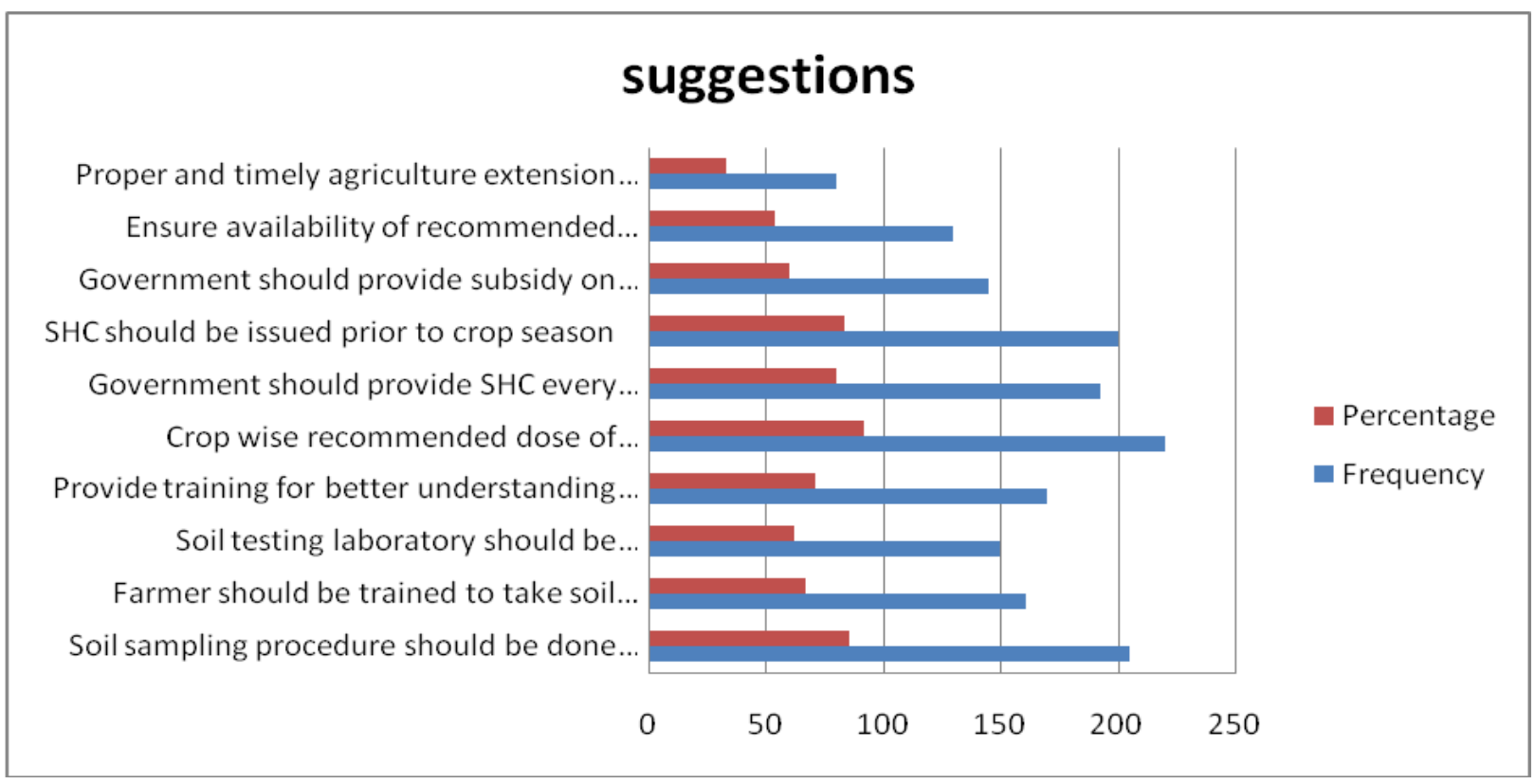

The data related to suggestions given by the respondents are presented in table 2 and ranked as I) Crop wise recommended dose of fertilizer should be given in the SHC (91.67\%), II) Soil sampling procedure should be done in presence of farmer $(85.42 \%)$, III) SHC should be issued prior to crop season (83.34\%), IV) SHC should be issued prior to crop season $(80.42 \%), \mathrm{V})$ Provide training for better understanding about content of Soil Health Cards $(70.83 \%), \mathrm{VI})$ Farmer should be trained to take soil sample of his own soil (67.08\%),VII) Soil testing laboratory should be established at taluka level with highly qualified staff $(62.50 \%)$, VIII) Government should provide subsidy on inputs used by farmers $(60.42 \%)$, IX) Ensure availability of recommended fertilizers in the market (54.17\%) and X) Proper and timely agriculture extension services $(33.33 \%)$.

An outlook of the constraints and suggestions elicited by respondents gives an idea that major constraints faced by the SHC holders about Soil
Health Card were difficult to calculate fertilizer dose on the basis of nutrient status of soil followed by time gap between soil samples taken and issuing cards is too high. Majority of the farmers had suggested that there should be provision of crop wise recommended dose of fertilizer should be given in Soil Heath Card. Timely availability of Soil Health Card to the farmers. An understanding of the perception of farmers and description of constraints faced by the respondents may serve as a feedback to the planers, policy makers, extension personnel, scientist and development agencies to make suitable strategy in implementation of the scheme.

\section{References}

Yadav, S. P. V., Raman, S.R. and Kumar, R. 2005. Knowledge and attitude farmers towards soil testing practices. Indian Research Journal of Extension Education. 6: $1-3$.

\section{How to cite this article:}

Lokesh Babu, S., T. Lakshmi and Prasad, S.V. 2019. Awareness and Perception of Farmers towards Soil Health Card Scheme in Rayalaseema Region of Andhra Pradesh. Int.J.Curr.Microbiol.App.Sci. 8(06): 2342-2346. doi: https://doi.org/10.20546/ijcmas.2019.806.278 